\title{
Finger Millet: An Alternative Crop for the Southern High Plains
}

\author{
Prasanna H. Gowda ${ }^{*}$, P. V. Vara Prasad ${ }^{2}$, Sangamesh V. Angadi ${ }^{3}$, Umesh M. Rangappa ${ }^{3}$, \\ Pradeep Wagle ${ }^{4}$ \\ ${ }^{1}$ USDA-ARS Grazinglands Research Laboratory, El Reno, OK, USA \\ ${ }^{2}$ Department of Agronomy, Kansas State University, Manhattan, KS, USA \\ ${ }^{3}$ Agriculture and Science Center, New Mexico State University, Clovis, NM, USA \\ ${ }^{4}$ Department of Microbiology and Plant Biology, and Center for Spatial Analysis, University of Oklahoma, \\ Norman, OK, USA \\ Email: * Prasanna.Gowda@ars.usda.gov
}

Received 26 September 2015; accepted 26 October 2015; published 29 October 2015

Copyright (C) 2015 by authors and Scientific Research Publishing Inc.

This work is licensed under the Creative Commons Attribution International License (CC BY).

http://creativecommons.org/licenses/by/4.0/

(c) (i) Open Access

\section{Abstract}

In the Southern High Plains, dairies are expanding to take advantage of favorable climatic conditions. Currently, corn (Zea mays L.) and forage sorghum [Sorghum bicolor (L.) Moench] are the two major crops grown in the region to meet silage demands for the expanding dairy industry, but they have relatively large water requirements of about 840 and $690 \mathrm{~mm}$, respectively, to achieve desirable results. With rising energy costs and declining water levels in the underlying Ogallala Aquifer, crops that use less water, like finger millet (Eleusine coracana (L.) Gaertn) could become alternate forage crops for dairies to corn or forage silage. In this study, we evaluated the adaptability of five finger millet accessions to the Southern High Plains and compared nutritional quality of their forage to that of corn and sorghum. Results indicated that finger millet can be grown in the Southern High Plains. Comparison of nutrient composition has shown that the quality of finger millet is relatively higher than that of corn and sorghum in terms of calcium, potassium, and phosphorus levels in their forage. However, potential forage yield of most commonly grown corn and sorghum in the region is higher than that of finger millet. Therefore, finger millet may provide a unique opportunity to improve the dairy-fed silage quality by mixing it with corn or sorghum silage while meeting the growing regional forage demand. Further field research is needed to measure its water requirements in the Southern High Plains.

\section{Keywords}

Ogallala Aquifer Region, Semi-Arid, Forage, Texas Panhandle

\footnotetext{
${ }^{*}$ Corresponding author.
}

How to cite this paper: Gowda, P.H., Prasad, P.V.V., Angadi, S.V., Rangappa, U.M. and Wagle, P. (2015) Finger Millet: An Alternative Crop for the Southern High Plains. American Journal of Plant Sciences, 6, 2686-2691. 


\section{Introduction}

Declining water resources is a major concern in the Southern High Plains (New Mexico and West Texas, Figure 1), where agriculture is the foundation for economic stability. Crop production in the region is dictated by irrigation water, which mostly comes from the Ogallala Aquifer underlying the Southern High Plains [1]. The Ogallala Aquifer, once considered a never-ending source of irrigation water, is declining rapidly in the region which has left many wells dry and crop production more risky. Although New Mexico (5.4\%) and Texas (20.4\%) account for $26 \%$ of total Ogallala Aquifer area, the amount of water that underlies these two states is very small (New Mexico 1.5\% and Texas 12\%) of the whole Ogallala Aquifer [2]. Irrigation efficiencies have improved considerably in the region with the adoption of center pivot, and more recently, subsurface drip irrigation systems. However, the availability of groundwater is also have decreased. In addition, many other water demands are competing for the groundwater resource. Therefore, new approaches are needed to improve water conservation and water use efficiency of crops in the region.

Southern High Plains has been one of the fastest dairy growing regions in the United States [3]. Animal density for dairies has doubled between 2002 and 2004 [4] in west Texas. Establishment of three large capacity cheese plants and favorable environment for the dairy industry are expected to accelerate dairy growth in eastern New Mexico and west Texas. In addition, west Texas has the highest concentration of beef cattle on feed in the country [4]. This large concentrated animal feeding operation in the region needs large quantities of good quality forages. Water requirement of cattle is minimal compared to the water required to produce large quantities of

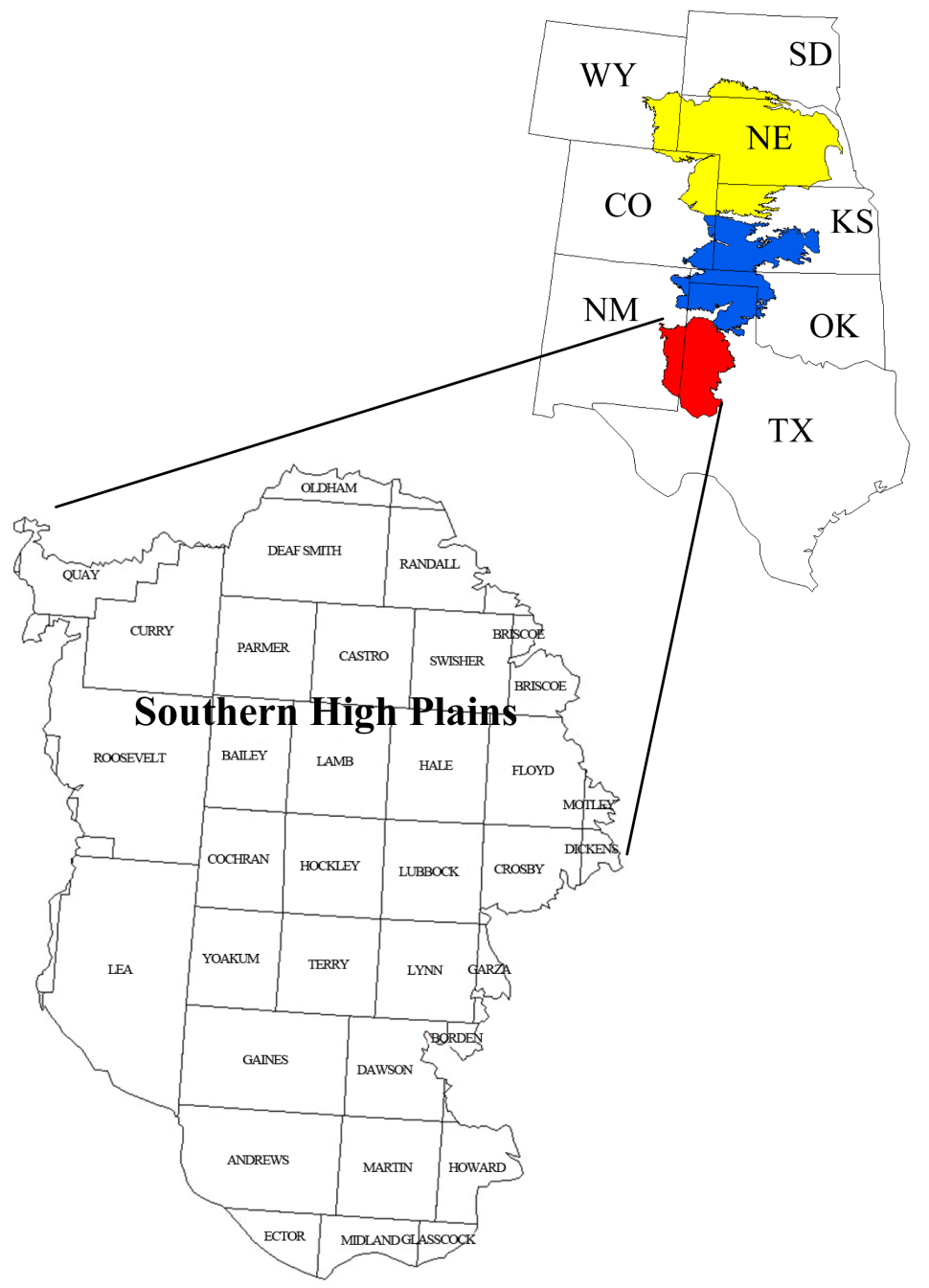

Figure 1. Location of the Southern High Plains in the south-central United States. 
good quality silage needed by the cattle. Therefore, to sustain the fast growing animal feeding operations in the region, new crops and cropping systems are needed to maintain quality forage production with less water use.

Currently, corn (Zea mays L.) and forage sorghum [Sorghum bicolor (L.) Moench] are the two major crops grown in the region to meet the current silage demand by the dairy industry. Corn silage is traditionally used to feed lactating dairy cows which require energy rich feed for maximum milk production. However, corn production requires a large quantity of water $(\sim 840 \mathrm{~mm})$, and reducing water resources in the region makes it difficult to sustain corn production. Sorghum is a more drought tolerant crop and has good potential as a silage crop with a reduced water requirement ( $\sim 900 \mathrm{~mm})$. However, nutritional quality concerns have reduced its acceptability by the industry. Finger millet (Eleusine coracana (L.) Gaertn), known to be highly tolerant to pests, diseases, and environmental stresses including drought, is currently grown in arid and semi-arid regions of the world.

Finger millet is a forage grass is also known as Koracan (Nigeria), Ragi (India), Bulo (Uganda), Wimbi (Swahili), and Telebun (Sudan). It is cultivated on more than 36 Mha globally [5] and 2 Mha of that in India in a region receiving rainfall less than or comparable to the Southern High Plains [6]. Although finger millet straw is used for feeding livestock in many Asian and African countries [7], it is mainly grown for food grain for human consumption [8] and also for brewing alcoholic/non-alcoholic beverages [9]. Finger millet exhibits a wide range of adaptability including thriving at higher elevations or higher salinity conditions compared with most other tropical cereals [10]. It is reported to use 10\% - 20\% less water than sorghum under irrigated conditions in arid conditions of southern India [11]. Forage yield of finger millet under irrigated conditions are nearly double compared to those in rainfed conditions and varies from 4.4 - 8.8 Mg·ha ${ }^{-1}$ under irrigation [10]. Under high input-intensive management, finger millet yields can exceed $15 \mathrm{Mg} \cdot \mathrm{ha}^{-1}$, which is reported in the Punjab state of India where finger millet is grown for silage under irrigation and three cuttings are taken annually [12].

Finger millet grain tastes good and is nutritionally rich as it contains high levels of protein and minerals such as calcium, iron, and manganese [8]. It also contains appreciable amount of methionine, an essential amino acid [13] lacking in most food grains. Most of the past research concentrated mainly on nutritional properties of the grain and has been reported mainly from India. However, climatic suitability of finger millet in the United States and nutrient quality of its forage are largely unknown. In this study, we evaluated the climatic adaptability of five finger millet accessions and compared nutritional quality of their forage to that of corn and sorghum in the Southern High Plains.

\section{Materials and Methods}

This study was conducted during the summer growing season of 2006 in the USDA-ARS Conservation and Production Research Laboratory (CPRL) located at Bushland, Texas [3511'N, 102 06'W] at $1170 \mathrm{~m}$ above mean sea level. Soils in and around Bushland are classified as slowly permeable Pullman clay loam (fine, mixed, superactive, thermic Torrertic Paleustoll) in texture. Average annual precipitation in the region is about $562 \mathrm{~mm}$, while about $835 \mathrm{~mm}$ of water is needed to grow grain corn (330 mm growing season rainfall), and $688 \mathrm{~mm}$ for grain sorghum (248 mm growing season rainfall) [14].

In this experimental study, five accessions of finger millet were evaluated. Selection of the accessions was based on their ability to produce forage yield and days required to maturity to avoid winter damage. Table 1 presents plant characteristics of five different finger millet accessions used in this study. Ten thousand seeds for each accession were received from the USDA-ARS Plant Genetic Resources Conservation Unit, Griffin, Georgia. Four accessions (PI271166, PI271167, PI462383, and PI462414) originated from India and the PI307693 originated from South Africa.

In the field experiment, about 5000 seeds for each accession were broadcasted on May 8, 2006 in a $1 \times 1 \mathrm{~m}$ plot and the 27-days old seedlings were transplanted in clumps on June 5, 2008. Each clump had 4 - 6 seedlings planted at $23 \mathrm{~cm}\left(9^{\prime \prime}\right)$ apart on $76 \mathrm{~cm}$ (30") wide rows. All four were flood irrigated immediately after planting and repeated whenever needed. After 30 days of planting, nitrogen fertilizer was applied at the rate of $125 \mathrm{~kg} N$ $\mathrm{ha}^{-1}$. After 120 days of planting, 10 plants were selected randomly from each accession and ground for assessing the forage quality. In addition, silage corn and silage sorghum samples were selected from neighboring plots grown as part of another study. Samples were sent to Dairy One Inc. ${ }^{1}$ to analyze for crude protein, neutral detergent fiber (NDF), non-fibrous carbohydrates (NFC), total digestible nutrients (TDN), in-vitro true digestibility (IVTD), and in-vitro NDF digestibility. Same nutritional qualities were also measured for corn and sorghum fo-

\footnotetext{
${ }^{1}$ Mention of trade or commercial products in this article is solely for the purpose of providing specific information and does not imply rec-
} ommendation or endorsement by the US Department of Agriculture. 
rages, and were compared and contrasted with that of finger millet accessions.

\section{Results and Discussion}

For selected five finger millet accessions, number of days from planting to maturity varied from 112 - 122 (Table 1). South African accession (PI307693) failed to germinate for unknown reasons. However, excellent germination (more than 90\%) was observed with all four Indian accessions. Considering the age of the seeds (see in Table 1), it was a great success. This is consistent with observations reported in the literature that finger millet seeds can be stored for a very long time without any treatments. Although the number of days required from planting to maturity was less than or equal to 122 days, none of the four accession senesced within that period. Only one accession (PI462414) senesced before freeze during late October, but exceeded more than 165 days. This unhindered growth with all four accessions may be due to availability of abundant solar radiation on the Southern High Plains combined with managed irrigation and adequate nutrient supply. The remaining three accessions were killed by cold temperatures before senescence. The plant height was consistent with the values reported in the Germplasm Resources Information Network (GRIN) database. Further, the number of tillers was more than 6-8 per plant with PI271166 and PI271167 accessions and 3 - 6 tillers per plant with PI462383 and PI462414 accessions. These results matched with the GRIN classification on tillering capacity for PI271167, PI462383, and PI462414 accessions. However, the observed tillering capacity of PI271166 accession did not match with the GRIN classification (Table 1).

Table 2 presents nutritional properties of four finger millet accessions, sorghum, and corn forages grown in the USDA-ARS CPRL, Bushland, Texas. Crude protein levels for finger millet accession PI271167 was significantly higher (14.6\%) than that of the remaining three finger millet accessions, corn, and sorghum. Corn silage had the least crude protein levels (7.4\%). NDF and TDN were comparable in all three crops. However, the NFC for finger millet accessions (20.1\% - 23.5\%) was significantly greater than that for sorghum (15.7\%) and comparable to corn (21.4\%). IVTD and NDFD at 30 hours for all four finger millet forages were equal or better than that for forage sorghum and corn.

Calcium content in finger millet accessions $(1.09 \%-1.29 \%)$ was found to be at least two times greater than that for the corn and sorghum silage (Table 2). In case of phosphorus levels, finger millet had 4 to 5 times greater levels than that in corn $(0.09 \%)$ and $90 \%-100 \%$ more than that in forage sorghum $(0.25 \%)$. Calcium and phosphorus are important minerals when formulating diets for dairy animals. Calcium and phosphorus deficiencies are frequently associated with reduction in appetite, retarded growth, decreased efficiency in feed utilization, decreased milk production, and impaired reproduction [15]. Further, greater magnesium content in finger

Table 1. Characterization of five different finger millet accessions.

\begin{tabular}{|c|c|c|c|c|c|}
\hline \multirow{2}{*}{$\begin{array}{c}\text { Trait } \\
\text { GRIN-ID }\end{array}$} & \multicolumn{5}{|c|}{ Characterization $^{*}$} \\
\hline & PI271166 & PI271167 & РI307693 & PI462383 & PI462414 \\
\hline Source & India & India & South Africa & India & India \\
\hline Maturity (days) ${ }^{* *}$ & 122 & 122 & 120 & 122 & 112 \\
\hline Plant height (m) & 1.0 & 1.1 & 1.1 & 0.7 & 0.8 \\
\hline Plant spread (m) & 1.0 & 1.0 & 1.1 & 0.6 & 0.5 \\
\hline Stem size & Large & Large & Large & Medium & Medium \\
\hline Tillering capacity & Medium & Abundant & Abundant & Medium & Medium \\
\hline Foliage amount & Abundant & Abundant & Abundant & Medium & Medium \\
\hline Seed production & Abundant & Medium & Abundant & Abundant & Abundant \\
\hline Resistance to winter damage & Complete kill & Complete kill & Complete kill & Complete kill & Complete kill \\
\hline Received year & 1961 & 1961 & 1965 & 1981 & 1981 \\
\hline
\end{tabular}

${ }^{*}$ GRIN. USDA, ARS, National Genetic Resources Program. Germplasm Resources Information Network-(GRIN). [Online Database] National Germplasm Resources Laboratory, Beltsville, Maryland. Available: http://www.ars-grin.gov/cgi-bin/npgs/html/desc.pl?102007 (29 September 2008).

${ }^{* *}$ Days from planting to first flower. 
Table 2. Nutritional properties of four finger millets, forage sorghum, and corn at the USDA-ARS Conservation and Production Research Laboratory, Bushland, Texas.

\begin{tabular}{|c|c|c|c|c|c|c|}
\hline \multirow{2}{*}{$\begin{array}{c}\text { Parameter }^{*} \\
\text { GRIN ID/plant name }\end{array}$} & \multicolumn{4}{|c|}{ Finger millet } & \multirow{2}{*}{ Forage sorghum } & \multirow{2}{*}{ Corn } \\
\hline & PI 271166 & PI 271167 & PI 462383 & PI462414 & & \\
\hline Crude protein (\%) & 10.8 & 14.6 & 9.7 & 7.9 & 9.2 & 7.4 \\
\hline NDF (\%) & 62.9 & 58.8 & 61.6 & 61.2 & 66.8 & 65.8 \\
\hline NFC (\%) & 20.1 & 21.1 & 21.9 & 23.5 & 15.7 & 21.4 \\
\hline TDN (\%) & 61 & 62 & 60 & 56 & 58 & 59 \\
\hline Calcium (\%) & 1.15 & 1.29 & 1.09 & 1.26 & 0.59 & 0.54 \\
\hline Phosphorus (\%) & 0.40 & 0.50 & 0.46 & 0.40 & 0.25 & 0.09 \\
\hline Magnesium (\%) & 0.31 & 0.34 & 0.28 & 0.30 & 0.31 & 0.15 \\
\hline Potassium (\%) & 4.26 & 5.08 & 4.93 & 3.86 & 2.34 & 2.88 \\
\hline Nitrates (\%) & 0.68 & 1.01 & 0.16 & 0.32 & 0.14 & 0.54 \\
\hline Nitrate-nitrogen (PPM) & 1256 & 2270 & 368 & 724 & 319 & 1224 \\
\hline IVTD $30 \mathrm{hr}$ (\% of DM) & 69 & 70 & 69 & 66 & 66 & 59 \\
\hline NDFD $30 \mathrm{hr}$ (\% of NDF) & 51 & 48 & 50 & 44 & 49 & 37 \\
\hline
\end{tabular}

*NDF: Neutral detergent fiber, NFC: Non fibrous carbohydrates, IVTD: In vitro true digestibility, TDN: Total digestible nutrients, and NDFD: In vitro NDF digestibility.

millet forages $(0.28 \%-0.31 \%)$ was observed than that in corn $(0.15 \%)$ and comparable to forage sorghum $(0.31 \%)$. Deficiencies in magnesium may be related to infertility, anemia or suppressed immune function in dairy cows [15]. Overall, higher levels of calcium, phosphorus, and magnesium in addition to comparable levels of remaining dietary requirements and digestibility indices, indicates that finger millet forage is as an attractive alternative to sorghum or corn forage if not a feed-additive to improve the quality of forage for dairy animals.

\section{Conclusion}

Comparison of nutritional properties indicated that quality of finger millet forage as feed to dairy livestock was greater than that of both corn and forage sorghum in terms of calcium, potassium, and phosphorus levels, while other nutritional levels were comparable. However, potential forage yield of corn and forage sorghum grown in the region is greater than that of finger millet. Therefore, finger millet may provide a unique opportunity to improve dairy-fed forage quality by mixing it with corn or sorghum while meeting the growing regional forage demand. The complimentary nutritional characteristic makes finger millet a potential candidate for intercropping with corn or sorghum to realize improved water use efficiency while increasing the quality of forage-based diets to dairy cows. However, further research is required to measure water requirements and forage yield of finger millet in the Southern High Plains of the Ogallala Aquifer region.

\section{References}

[1] Maupin, M.A. and Barber, N. (2000) Estimated Withdrawals from Principal Aquifers in the United States. US Geological Survey Circular, 1279.

[2] Guru, M. and Horne, J. (2000) The Ogallala Aquifer. The Kerr Center for Sustainable Agriculture, Inc., Poteau, 32.

[3] Hadjigeorgalis, E. (2005) The US Dairy Industry and International Trade in Dairy Products. Department of Agricultural Economics and Agricultural Business, New Mexico State University, Las Cruces.

[4] Texas Agricultural Statistics (2004) 2004 Texas Agricultural Statistics-Texas Agriculture by the Numbers. Texas Field Office, National Agricultural Statistics Service, Austin, 150 p.

[5] Food and Agriculture Organization of the United Nations (FAO) (2003).

[6] Covane, S.T., Jayaraman, N. and Senthil, N. (1995) Heterosis Study in Ragi [Eleusine corocana (L) Gaertn]. Journal of Phytology Research, 8, 53-56. 
[7] Sumathi, P., Joel, A. and Muralidharan, V. (2005) Combining Ability and Heterosis for Grain Yield and Its Component Traits in Finger Millet under Irrigated Conditions. International Sorghum and Millets Newsletter.

[8] Upadhyaya, H.D., Gowda, C., Pundir, R., Reddy, V.G. and Singh, S. (2006) Development of Core Subset of Finger Millet Germplasm Using Geographical Origin and Data on 14 Quantitative Traits. Genetic Resources and Crop Evolution, 53, 679-685. http://dx.doi.org/10.1007/s10722-004-3228-3

[9] Fernandez, D.R., Vanderjagt, D.J., Millson, M., Huang, Y.-S., Chuang, L.-T., Pastuszyn, A. and Glew, R.H. (2003) Fatty Acid, Amino Acid and Trace Mineral Composition of Eleusine coracana (Pwana) Seeds from Northern Nigeria. Plant Foods for Human Nutrition, 58, 1-10. http://dx.doi.org/10.1023/B:QUAL.0000040323.67339.cb

[10] Duke, J.A. (2005) Handbook of Energy Crops: Eleusine coracana (L.) Gaertn, Hort. purdue. edu [Consulté le 5 janvier 2005]. www.hort.purdue.edu

[11] Kissan (2006) Irrigation. http://ikisan.com/ap_irrigation.shtml

[12] Bogan, A.V. (1997) Tropical Pasture and Fodder Plants (Grasses and Legumes). Longman, London and New York, 111-126.

[13] The National Academies (1996) Chapter 2. Finger Millet. In: Lost Crops of Africa: Volume 1: Series. Board on Science and Technology for International Development, Office of International Affairs, National Research Council, 408 p.

[14] Gowda, P.H., Baumhardt, R.L., Esparza, A.M., Marek, T.H. and Howell, T.A (2007) Suitability of Cotton as an Alternative Crop in the Ogallala Aquifer Region. Agronomy Journal, 99, 1397-1403. http://dx.doi.org/10.2134/agronj2006.0275

[15] Harris Jr., B. (2003) Vitamins, Minerals and Dairy Cow Fertility. IFAS Extension, University of Florida, Gainesville, DS 47, 3 p. 